\title{
The Use of Code Switching in Responding to "Viral" Status on Instagram
}

\author{
Istiqamah Ardila \\ \{ardilaistiqamah@gmail.com\} \\ English Education Department, STAI Rasyidiyah Khalidiyah Amuntai, South Kalimantan, \\ Indonesia
}

\begin{abstract}
The popularity of Instagram really affects Indonesian people which anyone can share their pictures, videos, or words as status. Some of the status become viral and make thousands of comments come in responding to the viral status. Indonesian people usually switch their language in their communication online and offline. The researcher is interested in analyzing the comments of Indonesian people in responding the viral status on Instagram. The data focuses on comments of two viral scandal status uploaded on Instagram that have code switching. The function of code switching such as lack of facility, lack of register, mood of speaker, to show identity with a group and so on are found in the comments under three kinds of code-switching: tag-switching, intersentential code switching, and intrasentential code switching. This findings indicates that Indonesian people will switch their language to express their minds as well as feelings and make variation in their language.
\end{abstract}

Keywords: code switching; viral; Instagram

\section{Introduction}

In this millennial era, people use more than one language to communicate with others. They can be bilingual (two languages) or multilingual (many languages) based on how many languages that they are capable to speak. In this bilingualism and multilingualism, According to Malmkjaer [1] estimated that between 50 percent and 70 percent of the world's population are bilingual or multilingual - depending on the definition of bilingual itself and the multifaceted relationship between languages and dialects. Then, it leads to the phenomena which people use different codes in their utterances between two or more language in a single interaction include offline and online interaction.

The practice for using different code in utterances from one code to another code from different languages called code switching. In Indonesian context, people frequently utilize code switching between local language and national language (e.g. Javanese and Bahasa Indonesia) or national language and foreign language (e.g. Bahasa Indonesia and English). Their acts of switching are followed by several reasons like to signal familiarity or friendship, to create close social relationship and camaraderie, build closer social relationship, to show their prestige [2], trend [3], and to solve the problem of the complexisty of translating foreign language into Bahasa Indonesia [4]. 
Furthermore, the existence of social media like Facebook, Twitter, Instagram, YouTube, and so on have boarded the social interaction among Indonesian people. This interaction is stronger during Covid-19 pandemic. In the case of Instagram users around the word, Indonesia has become the fourth largest Instagram user with 93 million users in 2021 [5]. In addition, a study conducted by [6] found that Instagram becomes the second most used digital media by Indonesian Gen $\mathrm{Z}$ after Whatsapp application.

In this cyber world especially on Instagram, a status of a user in the form of pictures, videos or words can invite many comments from other users and becomes viral. It usually happen when the user has many followers and invite more than hundreds or thousands comments responding to the status. The viral status usually contains controversial issue related to public figure or government official. In this situation, Instagram users will use their language style to give comments including using code switching. Roles in practicing code switching on social media are to make qoutation, target spesification, repetition, qualification of message, clarification, importance, showing emotions, and free switching [7], [8]

The research on code switching on social media has been conducted through Facebook [9], [10], [11] Twitter [12], [13], [14a] YouTube [14], [15] and Instagram 16], [10], [3]. From the researches, all types of code switching are found by people in bilingual and multilingual society and country.

This research is intended to observed the practice of code switching used by Indonesian people in responding the viral status on Instagram during the pandemic. It is also expected to present information needed about the use of code-switching that occurs on social media especially Instagram.

Code switching discusses about the practice of using different codes from a language to others languages in a single interaction. Wardough [17] explained that people usually select a particular code and determine to used code switching from one code to another code or mix and create a new code in their utterance. This practice can be occurred both in bilingual and multilingual society [18], [19], [20]. In other word, code switching has function of personalization of the connotation 'we-code" to produce an uttarance [21]. In addition, code switching occurs when a speaker of bilingual society uses

Code switching entails the ability to switch from code A to code B [22]. It can be used to mark relationships, signaling status and situation, deference and intimacy [23]. There are purposes why people switch the codes such as to mention someone with qoutation, eligibile message, enlarge or highlight, convey confidentially, anger and annoyance, showing group identity (solidarity), exclude someone from conversation, change role of speaker, rise status, add authority, show expertise and continue the last language used [24]. Gardner-Chloros [25] stated code switching often occurs in conversation than in writing.

Poplack [26] stated that code switching is divided into three kinds: intersentential, intrasentential, and tag-switching. Intersentential switching appears when someone switches the code in a clause or a sentence like "Maka dari itu. I choose the way". Intrasentential switching happens within a clause or sentence in a conversation like "Iya driver online itu kan"; and tag-switching occurs when the use of a tag or short phrase from a language inserted into another language like I mean, you know, etc. Then, Appel and Muysken [27] explained six functions of code switching, they are:

1. Directive function: use to include or exclude someone from a conversation.

2. Expressive function: use to involve languge to show their identity.

3. Referential function: use when people cannot find the how to say the idea in a certain languge and switches to another language to say it more easily. 
4. Phatic function: use to highligth something by repeating it in both language.

5. Metalinguistic function: use to give comment about something by using another language.

6. Poetic function: use to make jokes showing a sense of humor in the switching.

In addition, people use code switching with certain purposes and reasons based on with whom they are talking to, the topic as well as the context of the conversation. Formulation of a framework to explain a phenomenon of using code switching on internet based on Malik's theory [28] is listed below.

1. Lack of facility: it happens when someone is hard to find the right words in his second language that match to his native language.

2. Lack of register competence: it occurs when a speaker is not competent in both language, then uses code switching. For example when he does know the term in both language, then choose English terminology that his partner and he are familiar with.

3. Mood of the speaker: it occurs when a speaker is in the moods of angry, anxious or nervous. It may happen when the act of code switching seems more practical in the certainmoment.

4. To emphasize a point: it occurs when a speaker has a choice to use code switching on certain part of utterance to emphasize a point.

5. Habitual expressions: it occurs in fixed phrases (greetings, commands, requests, apologies and discourse markers) such as o yes, you know, guys, etc.

6. Semantic significance: it occurs when code switching shows to convey semantically significant information based on participant's perception of two languages.

7. Group identity: it occurs when a speaker tries to show that he belongs to certain group or culture. He uses words from his native language to represent the sense of the group.

8. To address different audience: it occurs when speakers want to catch different listeners of recipients.

9. Pragmatic reasons: it occurs when speaker use code switching based on the context and emphasize varying degrees of speaker's involvement.

10. To attract attention: it occurs when a speakers wants to attract attention from audiences. It usually appears in advertisements which audiences interest to the language that they are familiar with first.

\section{Method}

This research used descriptive qualitative research to explain the particular social phenomenon in detail [29]. It provided both descriptive and statistical information to show the use of code switching in responding to viral status on Instagram. The subject of this research was the comments from two viral status on Instagram posted in February 2021 and March 2021. The viral status came from an account named@lambe turah that has ten million followers. Most of the status of this account becomeYo viral since it usually talks about hot issue from several aspect including public figures, government policy and others that really attach Instagram users' attention. Only comments which had actual code switching practices were considered in this research. A viral status, which talked about Sabyan's scandal, uploaded in February 2021 was succeed to invite 54.409 comments from other Instagram users. While the another viral status uploaded in March 2021 talked about a young man intimidated a middle-age woman worked as online driver (gojek) due to water splash from her motorcycle when she did her job as online driver (gojek). This status surprisingly gained 
23.352 comments from other Instagram users in responding to the bad attitude of the young man to the middle-age lady.

\section{Result and Discussion}

\subsection{Results}

\subsubsection{Code Switching Occurrence}

From the observation, three kinds of code switching were identified which are intrasentential, intersentential and tag switching. The code switching included the code switching of Bahasa Indonesia, local language, and foreign language.

\section{a) Intrasentential switching}

The comments that involve intrasentential switching like:

1. Ghosting ga nih? [Is it a ghosting?]

2. Lebih baek lagi apa lebih [It is better than before or ] GO PUBLIC lagi nih wkwkk

3. "atas kekhilafan yg saya lalukan" [for my err] marilah samo2 kito [let us] underline

4. Kalo ga goodlooking setidak nya setia kek [If you are not good looking, please be loyal]

\section{b) Intersentential switching}

The comments that involve intrasentential switching like:

1. Even until 1 billions people pun kalau lo nya sendiri yg ngk mau mengubah PERCUMA

[It is a waste time if the person doesn't want to change]

2. Cuman mau bilang [I just want to say] "ARE YOU READY KIDS??"

3. Kecipratan banyu udan mureng mureng. Medeni wong. Lebe koyo tewe

\section{c) Tag switching}

The comments that involve intrasentential switching like:

1. What?? Gitu doank?? [Just that??]

2. Damn ketahuan [it got caught]

3. It means dia mengakui gaes [he admit it guys]

\subsubsection{Code Switching Functions}

The act of code switching is followed by purposes, aims, and reasons [30], [1]. As has been analyzed above, all three kinds of code switching were used in comments of viral status on Instagram. Then, based on Edlin's framework related to the function of code switching, here are the uses of code switching by Instagram users in responding to viral status uploaded by@lambe_turah.

\section{a) Lack of Facility}

1. Satu kata buat anda: TAMBUK [One word for you: FUCK] 
2. You know nggilani [disgusting], yess you is NGGILANI lek [disgusting boy]

\section{b) Lack of Register}

1. Udah unboxing ga bang? [Have already unboxing bro?]

2. Udah unboxing pasti [She is unboxing]

\section{c) Mood of Speaker}

1. Khilaf? [Err?] You kidding me????

2. Gw rasa istri loe udah doain tiap malem...[I think your wife had already tapi masih khilaf terus, trus loe mau mohon Doa sama fans jadi lebih baik .... what??? situ sehat??

3. Dasar kamu doggy, , [You are doggy]

d) To Emphasize a Point

NGGRAGAS bin DOYAN [hooked and hooked]

\section{e) Habitual Experience}

1. It's okay semua orang juga pasti pernah berbuat salah, jangan sampai terulang

2. sampai ketiga kali [everyone ever do mistake, don't make it to the third]

3. Sorry bro udah gk respek lgi sama band anda [I have already unrespected to your band]

4. Kuda betinanya gak muncul nih??@nissa_sabyan ... [Where is the mare??] where are you @nissa_sabyan, jgn sok depresi [Don't be depressed]...ini hasil yg kamu tanam [this is the result of what you have planted]

\section{f) Semantic Significance}

1. The most bangke [shit] person in the world...

2. Selamat kehilangan [Happy losing] job

3. Udah viral aja baru bilang khilaf ! Waktu di warning sama bini gimana?! Kacau []

\section{g) Group Identity}

1. You know nggilani [disgusting], yess you is NGGILANI lek [disgusting boy]

2. Ayus

3. Ganteng kaga [not handsome], kaya kaga [not rich], kok bisa [how he can] doublekill?

4. Bungas kada, sugih kada, kada setia pulang ikam lah? [you are not handsome; you are not rich, and you are not loya?] Bye!

\section{h) To Address a Different Audience}

Sedih baca [I am sad after reading] spoiler buroto 55..kurama mati [kurama is death]

\section{i) Pragmatic Reasons}

1. Minta maaf udah pesen [apologize after order] connecting room 
2. Maaf sudah connecting kamar [Sorry but you had ordered connecting room]

\section{j) To Attract Attention}

1. Aku gak [I do not] likeeeee

2. Galikee (bacanya gelay) *kalo kata umi [I do not like (read it gelay) umi said]

\subsection{Discussion}

Three types of code switching are found in the comments of the viral status. Based on the result above, Instagram's users use Javanese, Banjarese, Bahasa Indonesia, and English in practiching the act of code switching. Many comments use intersentential code swithcing because it is easier to use among Indonesian people which they just insert a word or phrase as the code switching to show their reaction to the two viral status. Intrasentential code switching happens when a speaker switches one code to another code in a single conversation by inserting a word or phrase [30] like in the sentence ghosting ga nih? [is it a ghosting?] Then, the intersentential code switching is also found in the comments including Bahasa Indonesia and English. It can be seen from the first example that the user used English clause Even until 1 billion people in order to express her opinion related to Sabyan's scandal.Then, the next example is a sign or calling for Indonesian Instagram users (called nitizen) to attack the account of the character shown in the second status by saying "Are you ready kids??". After that, the tag code swithing is also found in the comments. Tag switching happens when a speaker use a tag, an idiom, an exclamation and a certain phrase and switch it to another language [30]. In the comments above, some users used word what?, damn, and it means that belong to English tag, idiom or certain phrase to their statements related to the viral status.

Related to the function of code-switching, the result shows that there are ten functions found in this study. First is lack of facility. The sentence that has this function is satu kata buat anda: TAMBUK [One word for you: FUCK]. Tambuk is Banjarese language refers to 'very fuck and stupid'. This term belongs to curse word and has very bad meaning. In this comment, user does not have Bahasa Indonesia vocabulary that match with the feeling of tambuk in Banjarese language. Thus, here switching is culturally conditioned. Next is lack of register as stated in the sentence: udah unboxing ga bang? [Have already unboxing bro?]. Unboxing is English word that usually occurs on Internet to open product's pack or take the product out of the box while the process is filmed. Here, the term is used to talk about the woman virginity since the status talked about cheating from marriage relationship. The version of this term in Bahasa Indonesia is hardly found to be used in public communication.

Then is mood of speaker. The sentence khilaf? [err?] You kidding me???? shows that the speaker is not believe with the statements on the viral status. It also reflects his emotion which is tired or angry to the viral status by choosing to use English to show his emotion. The other sentences such as dasar kamu doggy,,, [you are doggy]. The word doggy is belong to a curse word. It is a name of animal that imitiate to human. This word indicates that the person is so annoy and hate the content in the viral status.

Javanese and Bahasa Indonesia is found in the sentence nggragas bin doyan to highlight the point hooked and hooked. This uttarence has code switching function to emphasize a point. Also, the fixed phrases it's okay in the comments shows that the user use habitual expression in code switching. The next sentence belong to Bahasa Indonesia means that everything will be fine as long as the person do not repeat the same mistake in the future 
The next function includes code switching that conveys semantically significant information. The bangke word in the expression the most bangke person in the word conveys meaning of shit during code switching and job in the second expression meaning job in English. Then, the code switching can be used to show that the person belong to certain group. In the first example, the user inserted nggilani in the comment to show that she belongs to Javanese people. The use of English in her statement also show that she are capable to use English well. Then, the second example shows that the user use the word doublekill that usually occurs in Mobile Legend game. It indicates that he belongs to gamer community in the

game. In addition, the user use the word tambuk that belongs to Banjarese people. It indirectly show that he is a Banjarese.

The interesting code switching is found in the comment to address a different audience. Here, the user use spoiler followed by mention the title of manga or anime which is Naruto. It means that the user tries to address different audience that has same community with him in the code switching. The other comment belongs to pragmatic reasons which shows the context of the utterance connecting room refers to a type of hotel room that has special door between two different rooms. This term is booming when Ayus had ordered connecting room in a hotel to connect his room and Nisa room. Then, it frequently used by people to assert an idea if they talked about Sabyan's scandal.

Last is using code switching to attract attention. The sentence aku gak like means I do not like is readed gelay by Nisa. The term gelay is the same meaning with galike. The word ga from Bahasa Indonesia is added with the word like from English created the new word and new pronunciation gelay. This new word was very booming in line with the booming scandal. So, here the code switching by using galike [gelay] used to attract other users' attention.

\section{Conclusion}

The use of code switching in Indonesian bilingual and multilingual society reflects in their real conversation and their social media. In the social media especially Instagram, the use different code switching types occurs in responding to viral status namely intrasentential switching, intersentential switching, and tag switching. In addition, the code switching used by Instagram users in the comments include ten functions involve in the framework.

\section{Acknowledgments}

The aouthor would like to acknowledge to teacers and lectures involved for their help.

\section{References}

[1] N. P. A. Resmayani and D. P. Septarini, "Language and identity: code switching as communication device by Indonesian multilingual societies through Facebook status," in Proceedings Language in the Online \& Offline World 5: The Amplitude, Apr. 2016, pp. 332-337.

[2] C. E. A. Skujins, "Indonesian/English code-Switching on social media," Thesis, Flinders University, 2017. 
[3] Kamariah and Ambalegin, "Analysis of using code switching in Instagram," Journal BASIS, vol. 6, no. 2, pp. 259-266, 2019.

[4] D. Setiawan, "English code switching in Indonesian language", Universal Journal of Educational Research, vol.7, no.7, pp. 1545-1552, 2016.

[5] Statista, "Leading countries based on Instagram audience size as of July 2021," Statista.com, 2021. https://www.statista.com/ (accessed Aug. 09, 2021).

[6] F. Suwana, A. Pramiyanti, I. D. Mayangsari, R. Nuraeni, and Y. Firdaus, "Digital Media Use of Gen Z During Covid-19 Pandemic," Jurnal Sosioteknologi, vol. 19, no. 3, pp. 327-340, Dec. 2020, doi: 10.5614/sostek.itbj.2020.19.3.2.

[7] N. S. Halim and M. Maros, "The Functions of Code-switching in Facebook Interactions," Procedia - Social and Behavioral Sciences, vol. 118, pp. 126-133, Mar. 2014, doi: 10.1016/j.sbspro.2014.02.017.

[8] Sumarsih, M. Siregar, S. Bahri and D. Sanjaya "Code switching and code mixing in Indonesia: study in Sociolinguistics". English Language and Literature Studies, vol.4, no.1, pp.77-92, 2014.

[9] I. S. Lubis, S. Surya, and A. U. Muka, "The use of code-switching among the late adolencents in social media facebook," Calls: Jurnal of Culture, Arts, Literature, and Lingustics, Vol. 3, No. 2, p.83-96, 2017.

[10] C. Anisah, "The use of code-switching in Instagram and Facebook by Thai students in University of Muhammadiyah Malang (UMM)," Thesis, 2017.

[11] Indriyani, "A descriptive study of code mixing in social networking (Facebook) at SMK Muhammadiyah 3 Makassar," B.S. Thesis, English Edu. Depart., Muhammadiyah Univ. of Makassar, 2018.

[12] R. D. Sihombing and M. Meisuri, "Code switching in social media twitter," Linguistica: Jurnal of Linguistics if FBS UNIMED, vol. 3, no. 2, 2014.

[13] A. H. Samhan, "Social aspects in social media: code switching and code mixing in twitter," Research on Humanities and Social Sciences, Vol. 7, No. 8, p 110-115, 2017.

[14] W. Novianti, "The use of code switching in Twitter (a case study in English education department)", Passage, vol.1, n0.2, pp. 1-10, 2013

[15] D. Diandra, "Code switching and code mixing used by Boy William in breakout music program at net tv", B.S. Thesis STATE Islamic Institute of Palangkaraya, 2017

[16] H. C. Dewi, "Code-switching used by Indonesian celebrities on social media," Deiksis, Vol. 13, No. 3, p 222-230, 2021. doi: 10.30998/deiksis.v13i3.8669.

[17] N.P.E.M. Larasati, D.K. Tantra and I.G.A.L.P. Utami, "Code mixing and switching on 'Jun Bintang' captions on the Instagram", JPBII: Jurnal Pendidikan Bahasa Inggris Indonesia, vol. 9, no.1, pp. 37-44. 2021 doi: 10.23887/jpbi.v9i1.216

[18] R. Wardhaugh, An Introduction to Sociolinguistic, 7th ed. UK: Blackwell Publishing Ltd., 2015.

[19] O. Shay, "To switch or not to switch: Code-switching in a multilingual country," Procedia - Social and Behavioral Sciences 209, 462-469, 2015.

[20] N. M. N. I. Azlan and S. Narasuman, "The role of code-switching as a communicative tool in an ESL teacher education classroom," Procedia - Social and Behavioral Sciences 90, 458-467, 2013

[21] Isharyanti. "Code switching and code mixing in internet chatting: between ,yes ", ,ya"e and ,siee a Case Study. The JaltCall Journal, vol. 5, no. 3, pp. 67-78, 2009.

[22] Z.M.Nill and S.Paramasivam, "Code-Switching in Gol \& Gincu," Procedia - Social and Behavioral Sciences vol. 66, pp. 169 - 175, 2012. 
[23] Md. K. Hasan and Mohd. M. Akhand, "Reviewing the Challenges and Opportunities Presented by Code Switching and Mixing in Bangla," Journal of Education and Practice, vol. 6, no. 1, pp. 103-109, 2015.

[24] K. Malmkjær, The linguistics encyclopedia. London ; New York: Routledge, 2002.

[25] N. Yuliana, A. R. Luziana, and P. Sarwendah, "Code-Mixing and Code-Switching of Indonesian Celebrities: A Comparative Study,” Lingua Cultura, vol. 9, no. 1, p. 47, May 2015, doi: 10.21512/lc.v9i1.761.

[26] K. Malmkjær, The linguistics encyclopedia. London ; New York: Routledge, 2002.

[27] C. W. Fong, "Functions and Reasons for Code-Switching on Facebook by Utar English-Mandarin Chinese Bilingual Undergraduates," Research Project, Universitii Tunku Abdul Rahman, 2011.

[28] A. A. T. S. Eldin, "Socio Linguistic Study of Code Switching of the Arabic Language Speakers on Social Networking," International Journal of English Linguistics, vol. 4, no. 6, Nov. 2014, doi: 10.5539/ijel.v4n6p78.

[29] J. R. Fraenkel and N. E. Wallen, How to design and evaluate research in education, 7th ed. New York, Ny: Mcgraw Hill Education, 2008.

[30] Pieter Muysken, Bilingual speech: a typology of code-mixing. Cambridge, Uk: Cambridge University Press, 2000. 